\title{
How History Wars Shape Foreign Policy: An Ancient Kingdom and the Future of China-South Korea Relations
}

\author{
Peter Gries $^{1 \star}$ and Yasuki Masui ${ }^{2}$ \\ ${ }^{1}$ The University of Manchester, Manchester, United Kingdom of Great Britain and Northern Ireland and \\ ${ }^{2}$ Niigata Daigaku, Niigata, Japan \\ *Corresponding author. E-mail: peter.gries@manchester.ac.uk
}

(Received 18 December 2020; accepted 9 October 2021)

\begin{abstract}
Do history wars shape international affairs? If so, how and for whom? Taking the historical dispute between China and South Korea over the ancient Gaogouli/Goguryeo Kingdom as a case study, this article explores the individual-level psychological microfoundations of history wars. A 2020 survey experiment in South Korea pit "ours" vs "theirs" Goguryeo imitation Wikipedia entries to explore their downstream consequences. It revealed direct, indirect, and conditional effects. Exposure to China's claim to the Kingdom undermined Korean pride, increasing dislike of China, and lessening desires to cooperate with it. Pre-existing levels of nationalism divided South Koreans in how angry they became after exposure the Wikipedia primes. That anger, however, only shaped the China policy preferences of those South Koreans who viewed the balance of military power with China favorably. Implications for ownership disputes over kimchi and other national possessions are also discussed, as are the implications of history wars for war and peace in twenty-first-century East Asia.
\end{abstract}

Keywords: history wars; foreign policy; nationalism; public opinion; collective psychological ownership; pride; anger; national territory; China-South Korea relations; Goguryeo Kingdom

History wars are ubiquitous today-both within and between nations. Australians debate the impact of British colonization on Aboriginals: humane or genocidal? Leave and Remain voters in the UK differ not just over Brexit, but also in their attitudes towards the British Empire. The Summer 2020 Black Lives Matter (BLM) protests included the toppling of statues of the eighteenth-century British slave trader Edward Colston in Bristol, England, and of Confederate President Jefferson Davis in Richmond, Virginia. Because of their centrality to national identities in the present, disputes between fellow citizens over their shared national pasts are widespread.

(C) The Author(s), 2022. Published by Cambridge University Press on behalf of the East Asia Institute. This is an Open Access article, distributed under the terms of the Creative Commons Attribution licence (http://creativecommons.org/ licenses/by/4.0/), which permits unrestricted re-use, distribution, and reproduction in any medium, provided the original work is properly cited. 
National histories are also hotly contested between nations. For instance, most of China's territorial disputes with its neighbors are grounded in contentious historical claims. The "nine-dash line" or "cow's tongue" that surrounds the South China Sea on People's Republic of China (PRC) maps is based on the historical claim that Chinese first discovered the islands and reefs there and have been fishing them for nearly two millennia. Filipinos, Vietnamese, Indonesians and Malays are among those who fiercely disagree-based on rival historical claims.

While much has been written about history wars, there has been less attention to their precise consequences for war and peace. Historical disputes and international conflict certainly appear to go together. Nazi Germany's 1939 invasion of Czechoslovakia was tied to a historical claim to its "Sudetenland." Argentina's 1982 invasion of the British Falkland Islands was based on its historical claim to the "Islas Malvinas." And during the 1998-99 Kosovo War, then Serbian President Slobodan Milošević famously invoked the 1389 Battle of Kosovo to justify Serbian irredentism and a policy of ethnic cleansing against Muslims.

But even if they correlate, do history wars cause international conflicts, or are they the product of them? For instance, do historical claims to the South China Seas drive Chinese irredentism there? Or are historical declarations post facto rationalizations for a southward expansion driven by desires for strategic shipping lanes, energy resources, and fisheries?

And if there is a causal link running from history wars to international conflicts, what are its mediators and moderators? First, what mechanisms link the two? For instance, might intergroup emotions like anger or hurt pride result from challenges to historical ownership claims, prompting more negative views of the other country, subsequently increasing support for tougher foreign policies? Second, for what kinds of people and under what circumstances does any causal relationship hold? For example, might nationalists be more likely than cosmopolitans to be angered by challenges to national historical claims? And might the effects of that anger be contingent upon assessments of the relative strength of the two countries?

We explore these questions using the case study of the ancient Goguryeo Kingdom, which first straddled the borders of modern-day China and South Korea two millennia ago. Goguryeo is a "foundational myth" (Liu and Hilton 2005) for Korean nationalists, so highly salient to Korean identities in the present. Their history wars over the Kingdom first erupted in 2004 and coincided with a dramatic deterioration in China-South Korea relations. This makes it a consequential and arguably "most-difficult" case study to test the causal effect of history wars for international affairs: How could a dispute over 2,000-year-old history have soured such a mutually beneficial relationship in the present?

We draw on scholarship in nationalism studies and social psychology to address these questions. History wars, we suggest, implicate "national psychological ownership." Specifically, we integrate three literatures to explore what they can teach us about the political psychology of national possessions like past kingdoms: 1) nationalism scholarship on the social construction of nations across time and space, 2) psychological research on "collective psychological ownership" (CPO), and 3) intergroup emotion theory (IET). 
We embed an experiment in a nationally representative 2020 South Korean survey, testing the effects of exposure to "ours" vs "theirs" imitation Goguryeo Wikipedia entries on intergroup emotions, attitudes, and foreign policy preferences. This allows us to explore the individual-level psychological micro-foundations of history wars. By conducting the research in East Asia, and with a representative sample, we extend scholarship in psychology beyond its usual reliance on highly educated Western subjects (WEIRD; Henrich, Heine, and Norenzayan 2010).

To preview briefly, we find that history wars do indeed powerfully shape intergroup emotions like national pride and anger, and even more stable attitudes and foreign policy preferences. In addition to these direct causal effects, we also find that national emotions and attitudes both separately and sequentially mediate the impact of history wars on foreign policy preferences. We also find evidence of moderation: preexisting levels of nationalism and assessments of the military balance between China and South Korea condition the effect of emotional responses to history wars on China policy preferences.

Do these findings matter for foreign policy? The micro-macro link between individual-level psychology and national-level foreign policy operates both directly through foreign policy elites themselves, and indirectly through the influence of public opinion on those same elite decision-makers. First, elite politicians are not unlike the publics they represent; socialized within the same national contexts, they are likely to share similar psychological responses to history wars, directly impacting their foreign policy decision-making (Knecht 2010). Second, individual-level attitudes also have an indirect impact on foreign policy via public opinion. Self-interested policy makers, attuned to the "electoral connection," are responsive to the views of those who elect them (Tomz, Weeks, and Yarhi-Milo 2020). The micro-macro link, in short, appears robust: both foreign policy elites and public opinion powerfully shape national-level foreign policies, which subsequently shape regional and global system-level war and peace.

We begin with a brief overview of our case study, the China-South Korea dispute over the ancient Goguryeo Kingdom. We then integrate research in nationalism studies, collective psychological ownership, and intergroup emotions with the concept of "national psychological ownership," and propose three hypotheses about the effects of history wars on foreign policy preferences. We then introduce our experimental design, beginning with the "ours" vs "theirs" Wikipedia Goguryeo Kingdom experimental primes, followed by our survey measures. We then present our experimental results in two parts, beginning with the direct effects of exposure to the Wikipedia entries, before exploring more nuanced indirect and conditional effects. We conclude with thoughts on broader implications of our findings about the effects of history wars for other types of contested national possessions, and with recommendations for reducing national ownership disputes in twenty-first-century East Asia.

\section{A contested Kingdom}

China and South Korea first established diplomatic relations in 1992. The following decade witnessed a flowering of Sino-South Korean relations. As China prospered under "Reform and Opening," Koreans largely viewed their massive neighbor as a 
land of economic opportunity. By 2004 China had become South Korea's leading trade partner (Chung 2009).

But 2004 was also the year that the extended Sino-South Korean honeymoon came to a crashing end. On July 1, UNESCO approved China's application to have Gaogouli added to China's list of World Heritage Sites-where it remains today. ${ }^{1}$ Official Chinese media (e.g. Xinhua 2004) repeatedly referred to the Kingdom with the possessive language of “China’s Gaogouli" (中国高句丽). “Gaogouli was a regime established by ethnic groups in northern China some 2,000 years ago," Jilin University (China) professor Wei Cuncheng explained to China's official People's Daily (2004), "representing an important part of Chinese culture." The ancient kingdom was China's.

Goguryeo / Gaogouli (고구려 / 高句麗) was a kingdom located in the northern and central parts of the Korean Peninsula, and parts of Manchuria, for seven centuries starting nearly two millennia ago, from $37 \mathrm{BCE}$ to $668 \mathrm{CE}$. Twentieth-century Korean nationalists, from Sin Ch'aeho of the 1910s and 20s (Schmid 1997) to President Park Chung-hee (1970) of the 1960s and 70s, placed the Goguryeo Kingdom at the heart of their national histories. The Kingdom is thus arguably what Liu and Hilton (2005) call a historical "charter" or foundational myth. Unlike the more recent Korean Yi / Chusun Dynasty (1392-1897), which Korean nationalists see as subservient to China, the Goguryeo represented a virile and independent Korea. "Robbing Korea of Koguryo," Peter Gries $(2005,8)$ wrote, "is like robbing Korean nationalists of their manhood."

Indeed, the South Korean public was livid at China's claims to Korea's Goguryeo. Protestors demonstrated outside the Chinese embassy in Seoul. Cyber-nationalists established "Defend Goguryeo" websites. Newspapers were full of op eds denouncing China. China's ulterior motive, Seoul National University Professor of Korean History Song Ki-ho $(2004,93)$ argued, was to "literally 'steal away' Goguryeo history from the Korean people, who have always believed Goguryeo to be part of their own history." An August 16 Korea Herald poll revealed that only 6 percent of South Korea's National Assembly lawmakers viewed China as their most important diplomatic partner-a precipitous drop from the 63 percent that had seen China that way just four months earlier (Snyder 2004).

In a close reading of South Korean social media in 2010, Thomas Chase $(2011,71)$ found that anxiety over the "ownership" of Goguryeo persisted, generating both fear and pride. Korean netizens feared "Korea being castrated and disempowered." Perhaps as a response to this fear, Korean cybernationalists found strength in reasserting Goguryeo's independence from China, and its strength. "Goguryeo was variously described as an 'East Asian Hegemon,' a 'Great Power of East Asia,' a 'Warrior State,' or an 'Empire' that controlled a 'wide and endless land'" (Chase 2011, 71). Maps were frequently deployed to visually trumpet the Kingdom's size and power.

Many Chinese, meanwhile, continued to feel insulted by Korean rejections of a past Sinocentric regional hegemony (Gries 2012). "Koreans should look back with gratitude to their good fortune, rather than with resentment," wrote Wang Sheng (2010; cited in Rozman 2012, 273). This "arrogant" Chinese view, Princeton's Gil Rozman $(2012,281)$ argued in a thoughtful reading of Chinese sources, was pervasive. 
Hurt pride and anger surrounding the "history wars" persists in both South Korea and China today. South Korean Google Trends reveals that in the 17 years between January 1, 2004 and April 2021, searches for “고구려" (Goguryeo) peaked in September 2004 when the historical controversy between China and South Korean first emerged, and has fluctuated at around a quarter of that level over the past decade. "The Qing Dynasty was founded by Manchus ... descended from Goguryeo," South Korean nationalist Ahn Jung-kwon declared in a 2018 vlog. "So much of China today is really the territory of the Republic of Korea." ${ }^{2}$ Such claims appear to infuriate some Chinese. "I'm so angry!!!” a Chinese blogger wrote in 2020. “The Korean Gooks (棒子) are always shamelessly stealing other people’s things.”3

\section{National psychological ownership}

Soon after the Sino-Korean "history wars" first erupted in 2004, Yonson Ahn (2006) thoughtfully wrote that "national history serves as a clear-cut dividing line between 'our history' and 'theirs.' The rigidity of national history reproduces the image of the monolithic national 'self and 'other." This raises a central theoretic challenge for the political psychology of national histories and possessions: most work in both nationalism studies and social psychology has focused on the borders between-how and why a collective national "we" is produced and reproduced against national and other social "others"- "them." Less attention has been paid to the content of the nation: what is "ours" and what is "theirs."

The study of "national psychological ownership" also shifts our gaze from the coolly cognitive, social and psychological construction of nations, to the role of "hot" intergroup emotions. "The other's claim on 'our' history is branded as stealing, manipulating, or distorting history," Ahn (2006) also noted about the 2004 Goguryeo controversy, "so that 'we' need to correct and protect or rescue 'our' history." Threats to "our" historical claims stimulate intergroup emotions (Mackie, Devos, and Smith 2000) like national anger and pride. A political psychology of national ownership, we suggest, should also join in the revival of the study of emotion in sociology (Hochschild 1983) and psychology (Mackie, Devos, and Smith 2000) following its neglect during the behavioral revolution.

First, the constructivist turn in the social sciences and humanities has contributed to a view of both individuals and groups as socially constructed across both space and time. The individual is constituted through her interactions with others, as well as the stories she tells about her past. Sociologist Anthony Giddens argues that narratives provide the individual with "ontological security": "The reflexive project of the self ... consists in the sustaining of coherent, yet continually revised, biographical narratives" (Giddens 1991, 5). The storied nature of social life, personality psychologist Dan McAdams (2006) has similarly argued, infuses our individual identities with meaning.

Nationalism theorists have made similar arguments about national identities. Political elites, Benedict Anderson and Eric Hobsbawm first taught us, construct nations across space and time. In his Imagined Communities, Anderson (1983) highlights the construction of national space through print capitalism (e.g. newspapers, maps). In The Invention of Tradition, Hobsbawm and Ranger (1983) highlight the construction of national histories across time to naturalize new nations in the present. 
More recently, studies of banal and everyday nationalism have shifted attention from elite-led efforts to construct new nations, to the daily reproduction of existing nations by ordinary citizens (for a review, see Koch and Paasi 2016). For instance, where Anderson explored how political elites used maps and census to construct new postcolonial nations and define their legitimate inhabitants from the top-down, Catherine Dunlop (2015) has more recently shown how citizen-mapmakers demark national boundaries bottom-up.

Nationalism theorists, in short, have focused on the social production and reproduction of national identities across time and space, rather than what lies within them: national possessions. And national identity has largely been treated as an effect, with some attention to its domestic effects on nation-building. Less attention has been paid to the consequences of national identities for intergroup emotions, attitudes, and foreign policy preferences.

Social psychologists have also largely focused on the borders between social identities, rather than what lies within them. The predominant approach to intergroup relations, social identity theory (SIT; e.g. Tajfel and Turner 1986), focuses on "we" vs "them": how our social identities (e.g. gender, age, race/ethnicity) are constituted in relationship and shape intergroup behaviors. SIT"s "minimal ingroup paradigm" (Tajfel 1970) was successfully utilized to explore the minimal conditions producing intergroup discrimination. In SIT, social identities are largely treated as interchangeable black boxes, lacking prior histories or content.

Psychologists have recently begun to explore both 1) the psychology of group possessions, and 2) how our group memberships shape our emotions. First, psychological ownership fulfils needs for control. "A man's Self is the sum total of all that he CAN call his ... his clothes and his house, his wife and children, his ancestors and friends, his reputations and works, his land and horses, and yacht and bank-account," William James wrote well over a century ago about our personal identities, "If they wax and prosper, he feels triumphant; if they dwindle and die away, he feels cast down" (William James writing in 1890; cited in Verkuyten and Martinovic 2017, 1024).

Over a century later, organizational psychologists extended James' insight from the individual to the group, exploring how work teams claim collective ownership of their labor (Pierce and Jussila 2009). Research on "collective psychological ownership" (CPO) has since moved into social psychology, shifting attention from SIT's focus on the psychology of intergroup similarities and differences ("we" vs "them"), to the psychology of group possessions ("ours" vs. "theirs"). It distinguishes types of group ownership claims-and explores the consequences of threats to them. The "first possession" principle is that an object belongs to the first person or group to own it. It is frequently invoked in claims to territorial sovereignty-and anti-immigration discourses (e.g. Nijs, Martinovic, Verkuyten and Sedikides 2020). The "formative" principle of ownership is that an object or territory is constitutive of the historical identity of the group. For instance, many Jews claim ownership of Palestine because their early experiences there make it constitutive of what it means to be Jewish (Verkuyten and Martinovic 2017, 1026-27). Similarly, Goguryeo's perceived past independence and virility are constitutive of Korean national identity today-especially for Korean nationalists. 
Outgroup affirmation of ingroup ownership claims can reduce conflict: "good fences make good neighbors." However, threats to ingroup ownership can produce outgroup negativity and exclusion, as well as efforts to defend ingroup ownership claims. For instance, anti-immigrant rhetoric can invoke the unfairness of "no longer being master in one's own house" to justify outgroup exclusion (Verkuyten and Martinovic 2017; Nijs, Martinovic, Verkuyten, and Sedikides 2020; Selvanathan, Lickel and Jetten 2021).

Second, intergroup emotion theory (IET; e.g. Mackie, Devos, and Smith 2000) can help us better understand the emotions that history wars stimulate. Intergroup emotions are experienced by individuals on the basis of their identification with a salient group. For instance, Jetten and Wohl (2012) found that among those who identified strongly with England, threats to England's historical continuity produced collective angst (concern for the future vitality of England) - and opposition to immigration. Conversely, affirmation of continuity between England's national past and present provided high English identifiers with greater "existential security," reducing their opposition to immigration.

Emotions like pride and anger central to the Goguryeo controversy discussed above (e.g. Ahn 2006; Chase 2011) tend to share similar characteristics at the interpersonal and intergroup levels. The self-conscious emotion of pride stems from doing well in social comparison-whether in one's personal or group identities. Conversely, a loss of pride in a valued social identity, such as being Korean, is likely to express itself in negative intergroup attitudes (Tracy and Robins 2004) and behaviors (Bushman and Baumeister 1998). Similarly, whether aroused by a perceived slight to a personal or group identity, anger is an approach emotion associated with aggression against the offender (Carver and Harmon-Jones 2009).

In short, "national psychological ownership" involves feelings of possessiveness towards things associated with the nation, such as its history and territory (e.g. past kingdoms), as well as tangible objects (e.g. national foods and flags) and more intangible practices (e.g. singing the national anthem), to be discussed in the conclusion. It shifts our gaze from the borders between nations ("we" vs "them"), to what lies within them ("ours" vs "theirs"). It also transfers our focus from the cool cognitive processes involved in the social and psychological construction of national identities across time and space, to the hot affect of intergroup emotions like pride and anger-and their impact on international attitudes, cooperation, and conflict.

\section{Experimental design}

Recent scholarship with cross-sectional data from around the world has demonstrated the correlates of collective psychological ownership. For instance, primo-occupancy beliefs have been associated with opposition to Muslim rights in Holland (Smeekes, Verkuyten, and Martinovic 2015). CPO has also been associated with antiimmigration and anti-EU integration attitudes in both Holland and the UK, and Brexit voting in the UK (Nijs, Martinovic, Verkuyten, and Sedikides 2020). Similarly, Malay, White American, and White Australian supremacists are all more likely to endorse ownership claims to their countries-and to oppose progressive movements to expand minority rights (Selvanathan, Lickel, and Jetten 2021). 
There has been less work experimentally priming collective psychological ownership to demonstrate its causal effects. A territorial possession manipulation with Dutch subjects had a marginally significant impact on opposition to Muslim rights (Smeekes, Verkuyten, and Martinovic 2015, study 4). To our knowledge, however, there have been no experimental manipulations of the effects of CPO on foreign (vs domestic) policies. We therefore designed an experiment to see if priming "our" vs "their" past kingdoms would shape foreign policy preferences.

Based on the literatures reviewed above, we hypothesized direct, indirect, and moderated effects:

H1 (direct): outgroup challenges to national ownership claims will increase negative a) intergroup emotions and b) attitudes, and c) hostile foreign policy preferences.

H2 (indirect): Any direct effects on China policy preferences will be mediated by intergroup a) anger and b) pride, c) China attitudes, and d) intergroup emotions and China attitudes sequentially.

H3 (moderated): Individual differences will condition the above effects. Specifically, those higher in nationalism are more likely to respond angrily to challenges to ingroup ownership claims.

To test these hypotheses, we embedded an experiment at the end of the 2020 Korea Institute for National Unification (KINU) survey, which was conducted through face-to-face interviews from May 20 to June 10. Sampling on gender, age, and region, 1,003 South Korean adults participated, resulting in sample with $\mathrm{a} \pm 3.1$ percent sampling error. All participants read and signed lengthy consent forms on the first and last pages of the survey. It clearly stated that the survey followed Article 33 of South Korea's Statistics Act, fully protecting participant confidentiality.

\section{'Our' vs. 'Their' Kingdom Wikipedia primes}

We chose Wikipedia entries as our history wars manipulations both because Wikipedia is widely used in South Korea, and because different national versions are credible. The Korean Wikipedia Goguryeo entry is the first result of a Korean Google 4 search for “고구려.” Ingroup bias is pervasive in Wikipedia entries in different languages on shared past intergroup conflicts (Oeberst, Beck, Matschke, Ihme, and Cress 2020), so we reasoned that Korean participants would find not just a Korean Wikipedia entry, but also a Chinese Wikipedia entry trumpeting China's claim believable. The primes must be convincing to have impact.

Interviewers randomly gave each participant one of two different color paper copies, folded in half so they could only view and read a Wikipedia entry on the top half. After reading the entry and examining its map for at least a minute, they were instructed to unfold the page and answer the questions beneath it.

For the half randomly assigned to read the "our" condition, the instructions at the top of the page read in Korean, "The following is a description and map of Goguryeo 


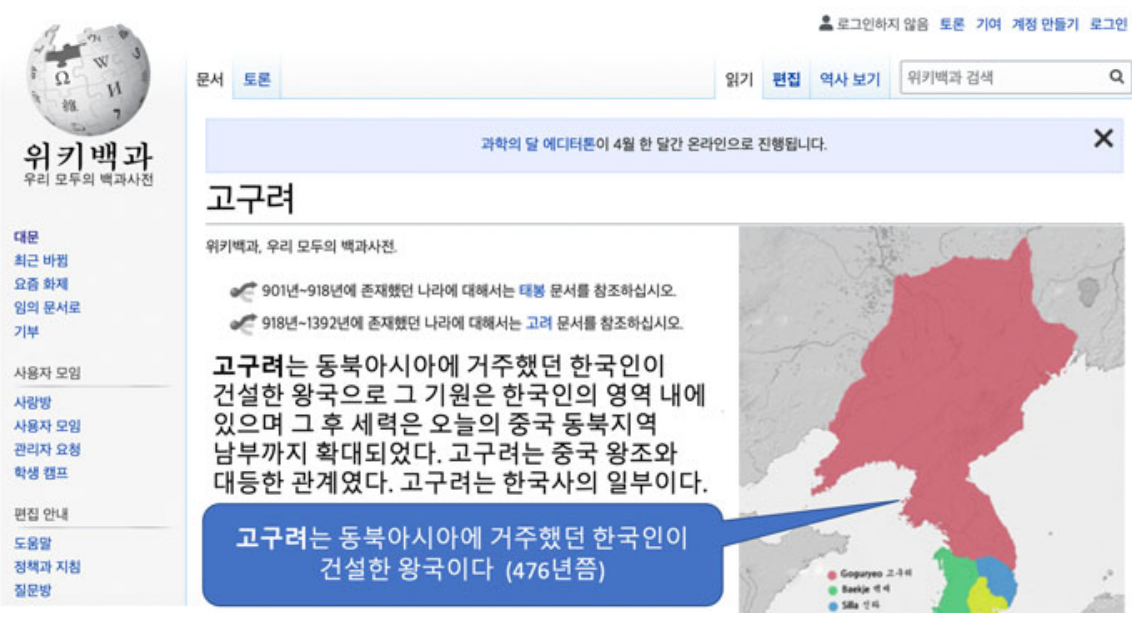

Figure 1. 'Our' Goguryeo Kingdom: Imitation Korean Wikipedia entry

from Wikipedia (an Internet Encyclopedia). Please read it carefully and answer the questions." (See the appendix for all original Korean language wordings)

The "our" Korean language "Goguryeo" Wikipedia entry read, "Goguryeo was a kingdom established by Koreans who lived in Northeast Asia. It originated within Korean territory, and later expanded into what is now the southern part of Northeast China. Goguryeo was an equal to the Chinese dynasties. Goguryeo is part of Korean history." This text, which was based upon the April 2020 고구려 (Goguryeo) Korean Wikipedia entry, repeatedly emphasizes that Goguryeo is Korean-“ours." This Korean historical ownership claim is based on both the first possession and formative principles.

This text was accompanied by a map (see Figure 1) that displayed Goguryeo as a large, unified territory spanning today's South and North Koreas, and China's Northeast. A callout explains the map: "Goguryeo was a kingdom built by Koreans who lived in Northeast Asia (around 476)."

The other half of the Korean participants who randomly received the "theirs" condition read the same instructions at the top of the page, with the addition of the single word "Chinese" (중국어) before "Wikipedia." That it was an outgroup Chinese Wikipedia entry was also made abundantly clear from its use of Chinese characters throughout, with Korean translations only in three callouts (see Figure 2). The Wikipedia entry header is “中国高句丽” in Chinese, with a callout, “Korean Translation: China's Goguryeo" in Korean.

The “original" Chinese language text, which was based upon the April 2020 高句丽 Chinese Wikipedia entry, was partially obscured by a large pull-out: "[Korean Translation] China's Goguryeo was a kingdom built by ancient peoples in the north-eastern region of China, and developed down the Korean Peninsula later. The Chinese dynasty viewed Goguryeo as a subordinate state, and the king of Goguryeo was appointed by the Chinese emperor. Goguryeo is part of Chinese history." This 


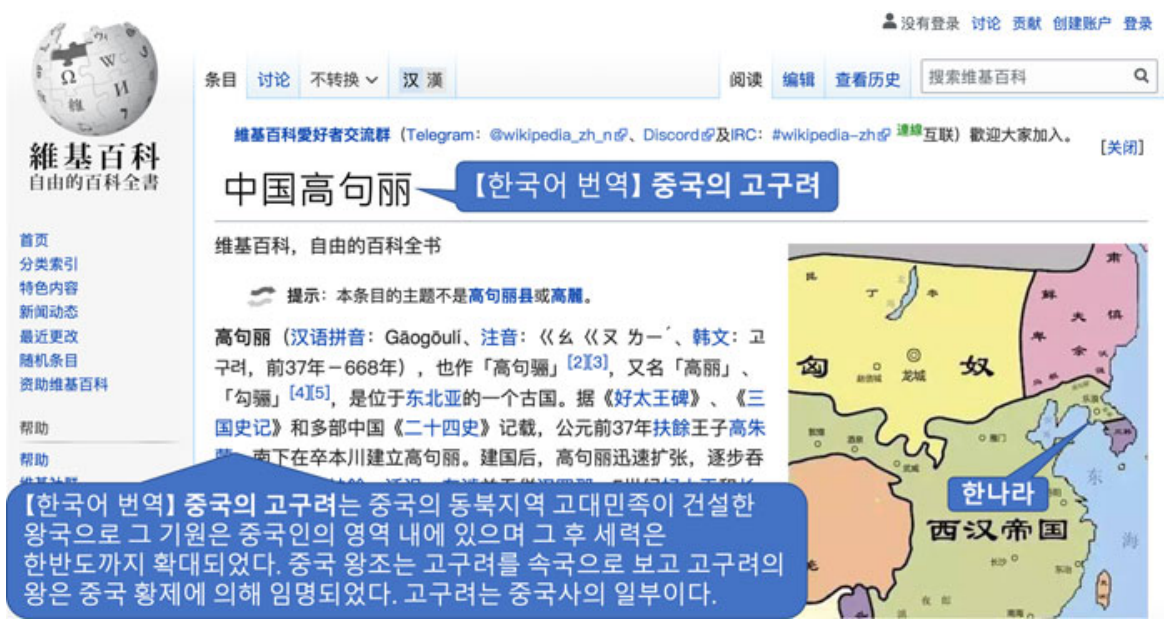

Figure 2. 'Their' (China's) Goguryeo Kingdom: Imitation Chinese Wikipedia entry, with Korean translations

text thus covers the same topics as the first, differing only in repeatedly emphasizing that Gaogouli is in fact China's - "theirs." The claim to Chinese possession is again based on both the first possession and formative principles of ownership.

The map in the Chinese Wikipedia "theirs" condition displays China's Han Dynasty (202 BCE-220 CE) extending out from central China across North Korea and into the northern part of South Korea. No separate Goguryeo is visible. A callout simply translates "Han Dynasty"into Korean.

\section{Measures}

All subsequent survey items were identical for all participants. The first question was a manipulation check to confirm that participants had read the Wikipedia entries and understood them as intended. "According to the Wikipedia entry you just read, and its map, Goguryeo is Korean." Responses were on a $1=$ strongly disagree to $7=$ strongly agree scale.

Intergroup emotions were then assessed with, "After reading the Wikipedia entry and viewing the map, as a South Korean to what extent do you feel the following emotions?” Embarrassment (당혹감), pride (자부심), and anger (분노) were each assessed, on a 1-7 rating grid from "not at all" to "very much." Embarrassment was a filler; we did not expect it to mediate the effects of the primes on the China variables.

A similar three item grid then tapped feelings of dis/like towards South Korea, North Korea, and China: "How much do you like or dislike ___ Please rate each of the following countries on a scale of -5 to 5 , where -5 is 'strongly dislike,' 0 is 'neither like nor dislike,' and 5 is 'strongly like."' We were interested in whether exposure to the Wikipedia entries would temporarily impact levels of dis/liking China; the other two countries were fillers. 
A final grid then assessed foreign policy preferences. Three items were rated on a 1 to 7 "strongly disagree" to "strongly agree" scale:

1. "We Koreans should cooperate less with China."

2. "Our foreign policy should prioritize making South Korea a leading power in Asia."

3. "It is my sincere wish that the two Koreas be unified."

The China policy item (1) was of primary interest; the other two were fillers.

Participants were then debriefed, "Thank you for participating. The Wikipedia entries in the questionnaire were imitations. Our research team is simply interested in how you reacted to them. Your responses will be recorded anonymously" (See appendix for Korean original). Participants were then asked some final demographic questions and released.

\section{Results}

\section{Direct effects}

An analysis of covariance (ANCOVA) controlling for gender and age revealed that exposure to the imitation Wikipedia entries worked as expected, with agreement to the manipulation check item, "According to the Wikipedia entry you just read, and its map, Goguryeo is Korean," substantially higher in the "our" $(M=5.59$, $S D=1.39)$ than "their" $(M=4.47, S D=2.08)$ condition, $F_{1,999}=101.75, p<.001$, $\eta_{p}^{2}=.09 .^{5}$

Similar ANCOVA on the intergroup emotions revealed three significant effects. As expected, those exposed to the "ours" Wikipedia entry $(M=5.20, S D=1.37)$ felt substantially more pride as Koreans than did those who read the Chinese "theirs" Wikipedia entry $(M=4.33, S D=1.86), F_{1}, 999=70.66, p<.001, \eta_{p}{ }^{2}=.07$. The effects were even larger for embarrassment and anger. "Their" Goguryeo $(M=5.26, S D=1.44)$ generated massively more embarrassment as a Korean than did "ours" $(M=3.56, S D=1.69), F_{1,999}=294.76, p<.001, \eta_{p}{ }^{2}=.23$. "Theirs" $(M=5.21, S D=1.47)$ also produced massively more anger than did "ours" $(M=3.42, S D=1.73), F_{1}, 999=316.88, p<.001, \eta_{p}{ }^{2}=.24$. For experiential work in psychology, these are extremely large effect sizes. H1a (direct effect on intergroup emotions) is strongly confirmed.

There was a small but statistically significant direct effect on feelings towards China, $F_{1,999}=9.84, p=.002, \eta_{p}^{2}=.01$. And it was in the expected direction, with "theirs" $(M=-1.58, S D=1.86)$ generating greater dislike of China than did "ours" $(M=-1.21, S D=1.87)$. H1b (direct effect on intergroup attitudes) confirmed. The primes had no direct effects on our filler items, feelings towards North Korea $\left(F_{1,999}=2.11, p=.15\right)$ or towards South Korea itself $\left(F_{1,999}=0.95, p=.33\right)$.

Finally, the foreign policy items. There was a small direct effect on "We Koreans should cooperate less with China," $F_{1,999}=6.32, p=.012, \eta_{p}{ }^{2}=.01$. And it was again in the expected direction, with "theirs" $(M=3.29, S D=1.29)$ generating more agreement that Koreans should cooperate less with China than did "ours" $(M=3.10$, $S D=1.18$ ). Reading a Chinese Wikipedia claim to Goguryeo, in other words, made 
Koreans less inclined to cooperate with China. H1c (direct effect on foreign policy preferences) confirmed. The Wikipedia primes again had no direct effects on the filler items, making South Korea a leading Asian power $\left(F_{1,999}=.15, p=.75\right)$ and Korean unification $\left(F_{1,999}=0.02, p=.90\right)$. So their effects were targeted.

In sum, a series of ANCOVA controlling for age and gender revealed that the "ours" vs "theirs" historical Kingdom Wikipedia primes worked as expected. There was a medium-large effect on the manipulation check, medium to very large effects on the intergroup emotions of pride, embarrassment, and anger as Koreans (H1a), and small but statistically significant effects on dis/like towards China (H1b) and desires to cooperate with China (H1c) - and all in the expected directions. Importantly, there were no spill-over effects on filler items, such as dis/like towards North and South Korea, or the Asia or reunification policy preference items. So the effect of history wars on attitudes and foreign policy preferences was targeted at the offending country and not indiscriminate.

\section{Indirect (mediated) and conditional (moderated) effects}

Did the intergroup emotions mediate the effects of the history war primes on dis/like and cooperation? A pair of simultaneous mediation analyses revealed just one indirect effect. Running SPSS v25 PROCESS v3.5 plugin model 4, with pride, embarrassment, and anger as simultaneous mediators, ours/theirs as the predictor, cooperation with China as the dependent variable, and age and gender as covariates, revealed no significant indirect effects. Running the same model, but with dis/like of China as the dependent variable, however, revealed only the indirect path via pride to be statistically significant. ${ }^{6} \mathrm{H} 2 \mathrm{a}$ (mediation through intergroup anger) is not confirmed; $\mathrm{H} 2 \mathrm{~b}$ (mediation through intergroup pride) is confirmed.

So, why would pride as a Korean-and not embarrassment or anger-mediate the impact of the history war primes on dis/like of China? Given that the primes had very large effects on embarrassment $\left(\eta_{p}^{2}=.23\right)$ and anger $\left(\eta_{p}^{2}=.24\right)$, and only a mediumsized effect on pride $\left(\eta_{p}^{2}=.07\right)$, this is perhaps surprising. It seems likely that it is the nature of the emotions themselves (rather than their magnitude) that shaped their downstream (non)effects on dis/like of China. First, embarrassment is a selfconscious emotion, and is often related to avoidant behaviors (Keltner and Buswell 1997) - moving away from the source of embarrassment. It was thus unlikely to shape approach-oriented attitudes and behaviors such as dis/liking or cooperating with China.

Second, anger is an approach emotion associated with movement towards its object, so seems more likely than embarrassment to shape dis/like of and (non)cooperation with China. However, anger usually only has its effects when the power balance is favorable. The weak do not usually express their anger at the strong; instead, they fear the strong (Carver and Harmon-Jones 2009). So perhaps it was unfavorable assessments of the military balance between China and South Korea that inhibited anger's downstream effects.

We can test this post-hoc hypothesis. The 2020 KINU survey also contained a question, "How powerful do you think the typical South Korean thinks that the following countries are militarily?" for six countries (North Korea, South Korea, China, 


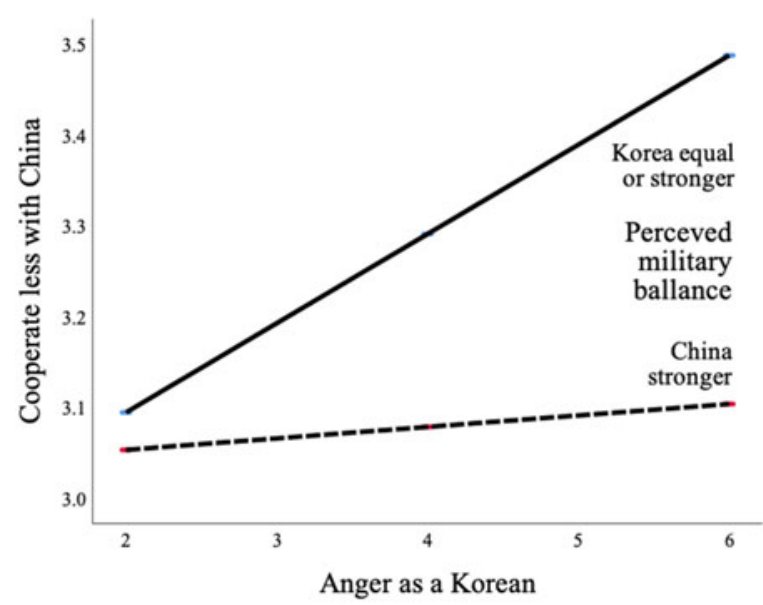

Figure 3. Anger as a Korean only shapes foreign policy preferences for those South Koreans who view the military balance of power with China favorably

Note: A moderation analysis run with SPSS v25 PROCESS v3.5 plugin model 1 . Statistics in text.

Russia, Japan and the USA). Responses were on a continuous 1-7 Likert scale from "very weak" to "very powerful."

On average, South Koreans thought that the typical South Korean viewed China $(M=5.43, S D=1.04)$ as significantly more militarily powerful than South Korea $(M=4.35, S D=.90), t(1002)=27.07, p<.001$. We subtracted assessments of South Korean from Chinese power to create a difference score, with higher numbers indicating greater relative Chinese military power. Using it as the moderator, anger as the IV, and cooperation with China as the DV in SPSS v25 PROCESS v3.5 plugin model 1 , produced a statistically significant interaction, $F(1,997)=5.83, p=.016$. As shown in Figure 3, anger only impacted foreign policy preferences (specifically, less cooperation with China) for those participants who viewed Korea as militarily equal to or superior to China (the rising upper line). For the majority of South Korean participants, who viewed China as more militarily powerful than Korea, there was no impact of their anger as a Korean on their cooperation preferences (the flat bottom line). This is why, at the full sample level, anger as a Korean did not mediate the relationship between the history wars prime and China policy preferences. $\mathrm{H} 2 \mathrm{a}$ is thus partially supported.

Preexisting levels of Korean nationalism moderated the effect of exposure to the Wikipedia primes on anger as a Korean. The 2020 KINU survey measured nationalism separately: "How superior is South Korea compared to other nations?" This nicely captures the sense of superiority over other countries central to nationalism (vs patriotism, which is more about ingroup love; Kosterman and Feshbach 1989). The response categories were on a four-point Likert-type scale from 1 = "vastly superior" to $4=$ "not at all superior," so were reverse coded (subtracted from five) so that a higher number indicated greater nationalism.

The line chart in Figure 4 displays how preexisting levels of Korean nationalism polarized the effect of exposure to the dueling historical claims to Goguryeo on 


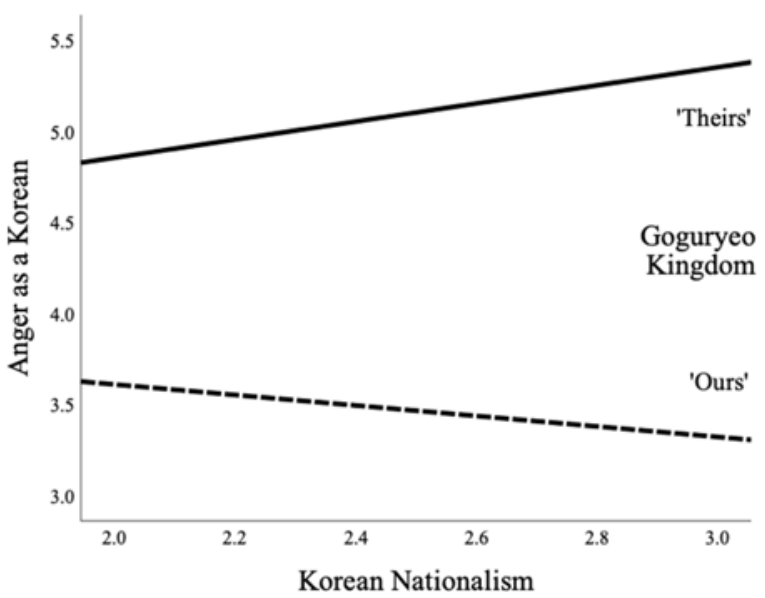

Figure 4. Preexisting levels of nationalism polarize the impact of dueling ownership claims to the Goguryeo Kingdom on anger as a Korean.

Note. A moderation analysis run with SPSS v25 PROCESS v3.5 plugin model 1 . The interaction was significant, $F_{1,997}=22.72, p<.001$.

anger as a Korean. Specifically, greater preexisting levels of Korean nationalism increased anger when exposed to the Chinese claim to Goguryeo (the top, upward sloping line), and decreased anger when exposed to an ingroup affirmation of Korea's own historical claim (the bottom, downward sloping line). H3 (nationalism moderates the impact of the historical ownership primes on intergroup anger) supported.

To summarize the conditional findings on anger, exposure to a rival claim to a cherished national kingdom produced anger compared to a reaffirmation of the historical/territorial claim. Furthermore, this effect on anger was polarized by preexisting levels of nationalism, with those South Koreans higher on nationalism getting angrier when exposed to the threatening Chinese claim to historical ownership (H3). This finding replicates earlier work finding that people with grandiose self-views who experience ego threat become the most aggressive (Bushman and Baumeister 1998). However, anger only subsequently impacted the foreign policy preferences (less cooperation with China) of those South Koreans who viewed the balance of national power favorably. Even when angered, the weak do not generally confront the strong (Sell, Tooby, and Cosmides 2009).

Third, pride stems from doing well in social comparison. A loss of pride in a valued social identity, such as being Korean, is likely to express itself in negative intergroup attitudes (Tracy and Robins 2004) and behaviors (Bushman and Baumeister 1998), such as disliking China and desiring less cooperation with it. It is this selfconscious and relational quality of pride that likely best explains why it alone among our three intergroup emotions mediated the impact of our history war primes on dis/liking China.

Would the emotion of pride as a South Korean and feelings of dis/like towards China sequentially mediate $(\mathrm{H} 2 \mathrm{~d})$ the impact of the "our" vs "their" kingdom primes 


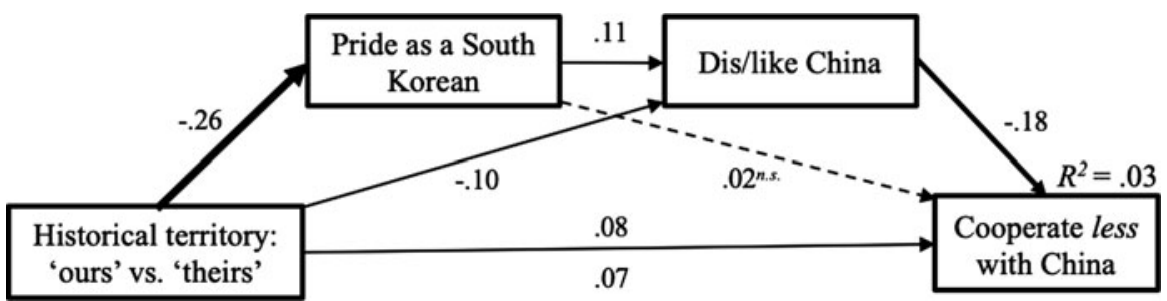

Figure 5. Exposure to Chinese claims to the Goguryeo Kingdom reduced pride as a South Korean, and cooled feelings towards China, reducing desires to cooperate with China

Note. A serial mediation model. Line thickness reflects the absolute weight of the standardized coefficient. Solid lines were all statistically significant; the dashed line was not. See text for indirect effect statistics.

on desires to cooperate with China? Running SPSS v25 PROCESS v3.5 plugin model 6 with age and gender as covariates reveals that they did. Figure 5 displays the results as a path model. The indirect paths via pride and dis/like China $(P E=.0107,95 \% C I$ from .0211 to .0028) sequentially, and China alone $(P E=-.0323,95 \% C I$ from -.0672 to -.0036$)$ were both statistically significant; the path via pride alone (the dashed line) was not $(P E=-.0134,95 \% C I$ from -.0550 to .0290$)$. In other words, a challenge to Korean possession of a valued historical territory (the Goguryeo Kingdom) shaped feelings of pride as a South Korean, feelings towards the transgressing country (China), and foreign policy preferences towards it (sequential mediation $\mathrm{H} 2 \mathrm{~d}$ supported).

Conclusions: Beyond History Wars

Sichuan's is the real kimchi. South Korea's version is merely pickles. - Chinese netizen on Weibo.com, $2020^{7}$

China's claim [to kimchi] is part of ... China's ambition to include Korean culture as theirs, distorting history and stealing. - South Korean netizen on Daum.net, $2020^{8}$

On November 29, 2020, China's nationalist Global Times declared in a headline that "China Sets International Standard for Kimchi." Sichuan Province had been granted an ISO listing for its pickled vegetables (paocai 泡菜). The ISO also clearly stated, however, that "this document does not apply to kimchi" (Kim and Ives 2020; Park 2020).

Many South Koreans were outraged. At their request, UNESCO had added Kimjang, the making and sharing of kimchi, to both North and South Korea's lists of "Intangible Cultural Heritage" in 2013. ${ }^{9}$ Kimchi is arguably constitutive of what it means to be Korean today. As the second epigraph above reveals, many South Koreans interpreted the Global Times' provocation as the latest in a long list of Chinese claims to cherished Korean possessions, from ancient historical kingdoms like Goguryeo, to signature Korean dishes like kimchi. And as the first epigraph 
shows, some Chinese netizens responded with claims to first possession of the pickled cabbage-and by denigrating Korean kimchi. Many themselves appear to feel that Koreans frequently poach upon China's own cultural heritage (Gries 2012).

The 2020 "kimchi clash" is yet another example of contestation over national psychological ownership, which can arouse feelings of possessiveness towards one's nation's things, from the past histories and kingdoms (e.g. Goguryeo) studied here, to national practices (e.g. kimjang, making kimchi) to national objects (e.g. kimchi itself) to be further discussed below. In this article, we have built on existing work in nationalism studies and social psychology, shifting our gaze from the borders between national and other social identities ("we/us" vs "they/them"), to what lies within them ("ours" vs "theirs"). By focusing on national possessions/ownership, we have also joined those seeking to complement analyses of the cool, cognitive construction of national identities across time and space, with explorations of how national identities can arouse intense intergroup emotions-and their impact on foreign policies.

We designed and implemented an experiment, embedded within a nationally representative 2020 South Korean survey, that pit "ours" vs "theirs" claims to ownership of the Goguryeo Kingdom. Results revealed that such "history wars" do indeed impact ordinary South Koreans, powerfully shaping intergroup emotions like national pride and anger, and even shaping more stable attitudes of dis/like towards China, and even China policy preferences. (H1a, b, and c all confirmed).

Moderation analyses further revealed that preexisting levels of nationalism polarized the effects of exposure to the opposing ownership claims to the past Kingdom on feelings of anger as a Korean. Specifically, more nationalistic Koreans experienced greater anger in response to the rival Chinese claim to Goguryeo, but also less anger when Korea's ownership of Goguryeo was affirmed (H3 confirmed). Another moderation analysis revealed one reason why that anger was not more consequential: it only shaped desires to cooperate less with China among that minority of Koreans who viewed South Korea as equally or more militarily powerful than China. For the majority, who viewed the balance of power with China less favorably, there was no impact of their anger on their China policy preferences. We do not generally confront those we see as stronger than us (Sell, Tooby, and Cosmides 2009).

Finally, mediation analyses further revealed that it was national pride that had the most pervasive effects on downstream attitudes and policy preferences (H2b confirmed). Specifically, exposure to "their" (vs. "our") claim to historical ownership of the Kingdom reduced pride as a Korean, which both increased dislike of China ( $\mathrm{H} 2 \mathrm{c}$ confirmed), and subsequently reduced desires to cooperate with China (H2d confirmed).

\section{Future directions}

As the kimchi/kimjang conflict suggests, future work on the political psychology of national possessions could move beyond history wars to explore conflicts between nations over different kinds of valued national "things" and practices. Do the distinctions between national histories, territories, objects, and practices matter for the 
political psychology of national ownership? Nationalism studies have focused on the re/production of the nation across space and time. Social psychologists are similarly divided between those who study the threat that immigrants pose to the collective psychological ownership of national spaces, and those who focus more on threats to collective memories and historical continuity. That both lines of scholarship focus on territory and history clearly suggest their centrality to national identities in the present. Our China-South Korea dispute over the ownership of the Goguryeo Kingdom may have had such large effects on intergroup emotions because it challenged both territorial and historical claims simultaneously.

Are conflicts over other types of national possessions as likely to inspire such strong emotions? Gastro-nationalist disputes, such as the recent Sino-Korean kimchi clash, or the nascent dispute between Russia and Ukraine over borsht, are about what we eat, so may evoke strong formative claims to ownership. And what of objects that we wear, like the Hanfu vs hanbok Sino-Korean traditional clothing dispute, or fabrics, like Indonesia and Malaysia's contending claims to batik? Because these "national" foods and clothing are constitutive of national identities in the present, they seem likely to be similarly pridefully protected.

Does "intangible" cultural heritage elicit the same psychological possessiveness? Are national practices, such as kimjang, as constitutive of national identities as historical and territorial possessions are? What of national festivals? In 2005, South Korea applied to UNESCO and was granted recognition for its Dano (단오) dragon boat festival as its "Intangible Cultural Heritage." Many Chinese, however, view it as China's own Duanwu (端午) festival, contributing to a pervasive Chinese view of South Koreans as cultural thieves.

The role of the perceived balance of power in moderating the effect of intergroup anger on foreign policy preferences also suggests a line of future research. South Koreans were substantially divided in their views of the South Korea-China balance of power such that anger only impacted the China policy preferences among those who viewed the balance relatively favorably. For weaker countries where more people view the balance of power with an offending country more unfavorably, might anger have less of an impact? And for stronger countries like China and the US, might more favorable views of the balance of power vis-à-vis most offending countries strengthen the impact of anger on their policy preferences?

\section{Policy implications}

A better understanding of the political psychology of national possessions can inform conflict resolution in a twenty-first century where populism and nationalism are flourishing. In a largely tribal world, respecting fences-not claiming "theirs" as "ours"-makes good sense. To promote peace, we need to affirm rather than challenge reasonable national ownership claims-whether to national histories, territories, objects, or practices.

We should also, however, learn to embrace cultural and national mixing (on polyculturalism, see Morris, Chiu, and Liu 2015). Rather than insist that all of "our" national possessions are and have always been unique, essentializing national differences, we need to celebrate how our nations have benefited from our 
interconnections. Italian cooking was enhanced by tomatoes from the new world. British social life was enriched by tea from China. Chinese religion (Chan Buddhism) and philosophy (neo-Confucianism) flourished with the arrival of Indian Buddhism. And Japanese Zen Budhism developed out of China's Chan Buddhism. When we learn to celebrate how "ours" benefited from "theirs," perhaps, we will feel less need to police our national possessions.

Acknowledgments. The first author would like to thank Sangsin Lee (이상신) and the Korea Institute for National Unification (통일연구원) for embedding our experiment within their 2020 annual survey.

Conflicts of Interest. The authors declare none.

Data Availability Statement. Replication data is available from the first author's dataverse.harvard.edu webpage.

\section{Notes}

1. https://whc.unesco.org/en/list/1135/, accessed 25 Nov. 2020.

2. 천리안, "고구려의 후손인 만주족이 세운 청나라 ... 중국 땅의 상당부분은 대한민국의 영토가 됩니다"; Ahn Jung-kwon, cited by "Clairvoyance," December 28, 2018, https://m.blog.naver.com/ zealot01/221428752960, accessed November 25, 2020.

3. “气死了！！！棒子老是偷别人的东西不羞耻”; “Vitality girl,“ www.douban.com/group/topic/182233882/ ?dt_dapp=1, accessed November 25, 2020.

4. With 81 percent market share, Google is the most widely used search engine in South Korea.

5. Partial eta squared $\eta_{p}{ }^{2}$ is an effect size statistic used in reporting of analysis of variance (ANOVA) results. A $\eta_{p}{ }^{2}$ of .1 can be interpreted as small, .06 as medium, and .14 and over as large (Cohen 1988).

6. $P E=-.0895,95$ percent confidence intervals with 5,000 bootstraps, from LLCI $=-.1596$ to ULCI $=$ -.0252 .

7. Cited in Kim and Ives 2020.

8. Cited in Park 2020.

9. See https://ich.unesco.org/en/RL/kimjang-making-and-sharing-kimchi-in-the-republic-of-korea-00881, accessed December 2, 2020.

\section{References}

Ahn, Yonson. 2006. “The Korea-China Textbook War-What's It All About?” Japan Focus, Feb. 29.

Anderson, Benedict. 1983. Imagined Communities: Reflections on the Origins and Spread of Nationalism. New York: Verso.

Bushman, Brad J., and Roy F. Baumeister. 1998. “Threatened Egotism, Narcissism, Self-Esteem, and Direct and Displaced Aggression: Does Self-Love or Self-Hate Lead to Violence?” Journal of Personality and Social Psychology 75 (1): 219-29.

Carver, Charles S., and Eddie Harmon-Jones. 2009. "Anger is an Approach-Related Affect: Evidence and Implications.” Psychological Bulletin 135: 183-204.

Chase, Thomas. 2011. "Nationalism and the Net: Online Discussion of Goguryeo History in China and South Korea." China Information 25 (1): 61-82.

Chung, Jae Ho. 2009. "China's 'Soft' Clash with South Korea: The History War and Beyond.” Asian Survey, 49: 468-83.

Cohen, Jacob. 1988. Statistical Power Analysis for the Behavioral Sciences. Mahwah, NJ: Lawrence Erlbaum.

Dunlop, Catherine Tatiana. 2015. Cartophilia: Maps and the Search for Identity in the French-German Borderland. Chicago: University of Chicago Press.

Giddens, Anthony. 1991. Modernity and Self-Identity: Self and Society in the Late Modern Age. Stanford: Stanford University Press. 
Gries, Peter. 2005. “The Koguryo Controversy, National Identity, and Sino-Korean Relations Today,” East Asia 22: 3-17.

—. 2012. "Disillusionment and Dismay: How Chinese Netizens Think and Feel About the Two Koreas," Journal of East Asian Studies 12: 31-56.

Henrich, Joseph, Steven J. Heine, and Ara Norenzayan. 2010. "The Weirdest People in the World?" Behavioural Brain Sciences 33 (2-3): 61-83.

Hobsbawm, Eric J., and Terence O. Ranger, eds. 1983. The Invention of Tradition. Cambridge: Cambridge University Press.

Hochschild, Arlie. 1983. The Managed Heart: Commercialization of Human Feeling. Berkeley: University of California Press.

Jetten, Jolanda, and Michael J. A. Wohl. 2012. "The Past as a Determinant of the Present: Historical Continuity, Collective Angst, and Opposition to Immigration." European Journal of Social Psychology 42 (4): 442-50.

Keltner, Dasher, and Brenda N. Buswell. 1997. "Embarrassment: Its Distinct Form and Appeasement Functions." Psychological Bulletin 122 (3): 250-70.

Kim, Youmi, and Mike Ives. 2020. "Is China Laying Claim to Kimchi, Too? Some South Koreans Think So." New York Times, December 2.

Koch, Natalie, and Anssi Paasi. 2016. "Banal Nationalism 20 years On: Re-Thinking, Re-Formulating and Re-Contextualizing the Concept," Political Geography 54: 1-6.

Kosterman, Rick, and Seymour Feshbach. 1989. "Toward a Measure of Patriotic and Nationalistic Attitudes." Political Psychology 10 (2): 257-74.

Knecht, Thomas. 2010. Paying Attention to Foreign Affairs: How Public Opinion Affects Presidential Decision Making. State College: Pennsylvania State University Press.

Liu, James H., and Denis J. Hilton. 2005. "How the Past Weighs on the Present: Social Representations of History and Their Impact on Identity Politics." British Journal of Social Psychology 44 (4): 537-56.

Mackie, Diane, M., Thierry Devos, and Eliot R. Smith. 2000. "Intergroup Emotions: Explaining Offensive Action Tendencies in an Intergroup Context." Journal of Personality and Social Psychology 79 (4): 602-616.

McAdams, Dan P. 2006. The Redemptive Self: Stories Americans Live By. New York: Oxford University Press.

Morris, Michael W., Chi-yue Chiu, and Zhi Liu. 2015. "Polycultural Psychology." Annual Review of Psychology 66: 631-59.

Nijs, Tom, Borja Martinovic, Maykel Verkuyten, and Constantine Sedikides. 2020. "This Country is OURS': The Exclusionary Potential of Collective Psychological Ownership." British Journal of Social Psychology 60 (1): 171-95.

Oeberst, Aileen, Ina Beck, Christina Matschke, Toni Alexander Ihme, and Ulrike Cress. (2020). "Collectively Biased Representations of the Past: Ingroup Bias in Wikipedia Articles about Intergroup Conflicts." British Journal of Social Psychology 59 (4): 791-818.

Park, Chung-hee. 1970. Our Nation's Path: Ideology of Social Reconstruction. Seoul: Hollym.

Park, Ji-won. 2020. "Kimchi Controversy: China's Cultural Provocation.” Korea Times, December 2.

People's Daily. 2004. "China's Ancient Koguryo Kingdom Site Added to World Heritage List," July 2.

Pierce, Jon L., and Iiro Jussila. 2009. "Collective Psychological Ownership Within the Work and Organizational Context: Construct Introduction and Elaboration." Journal of Organizational Behavior 31 (6): 810-34.

Rozman, Gilbert. 2012. "History as an Arena of Sino-Korean Conflict and the Role of the United States." Asian Perspective 36 (2): 263-85.

Schmid, Andre. 1997. "Rediscovering Manchuria: Sin Ch'aeho and the Politics of Territorial History in Korea," The Journal of Asian Studies 56 (1): 26-46.

Sell, Aaron, John Tooby, and Leda Cosmides. 2009. "Formidability and the Logic of Human Anger." Proceedings of the National Academy of Sciences 106 (35): 15073-78.

Selvanathan, Hema Preya, Brian Lickel, and Jolanda Jetten. 2021. "Collective Psychological Ownership and the Rise of Reactionary Counter-Movements Defending the Status Quo." British Journal of Social Psychology 60 (2): 587-69.

Smeekes, Anouk, Maykel Verkuyten, and Borja Martinovic. (2015). Longing for the Country's Good Old Days: National Nostalgia, Autochthony Beliefs, and Opposition to Muslim Expressive Rights. British Journal of Social Psychology 54 (3): 561-80. 
Snyder, Scott. 2004. “A Turning Point for China-Korea Relations?” Comparative Connections 6 (3): https:// cc.pacforum.org/2004/10/turning-point-china-korea-relations/.

Song, Ki-ho. 2004. "China's Attempt at 'Stealing' Parts of Ancient Korean History," Review of Korean Studies 7 (4): 93-122.

Tajfel, Henri. 1970. "Experiments in Intergroup Discrimination.” Scientific American 223 (5): 96-102.

Tajfel, Henri and John C. Turner. 1986. “The Social Identity Theory of Intergroup Behavior.” In Psychology of Intergroup Relations, edited by Stephen Worchel and William G. Austin, 7-24. Chicago: Nelson-Hall.

Tomz, Michael, Jessica L. P. Weeks, and Keren Yarhi-Milo. 2020. "Public Opinion and Decisions About Military Force in Democracies.” International Organization 74 (1): 119-43.

Tracy, Jessica L. and Richard W. Robins. 2004. "Putting the Self into Self-Conscious Emotions: A Theoretical Model.” Psychological Inquiry 15 (2): 103-25.

Verkuyten, Maykel, and Borja Martinovic. 2017. "Collective Psychological Ownership and Intergroup Relations.” Perspectives on Psychological Science 12 (6): 1021-39.

Wang, Sheng. 2010. "Shixi dangdai Hanguo minzuzhuyi" [An Analysis of Contemporary South Korean Nationalism]. Xiandai Guoji Guanxi [Contemporary International Relations), 2: 36-41.

Xinhua. (2004). "World Heritage Site: Capital Cities and Tombs of China's Ancient Koguryo Kingdom," July 3.

\section{Appendix of Original Korean and Chinese Language Wordings}

Instructions. 다음은 위키백과 (인터넷 백과사전) 의 고구려에 대한 설명과 지도입니다. 천천히 잘 읽어보시고 질문에 답해주십시오.

“Our” Goguryeo Korean language Wikipedia entry: 고구려는 동북아시아에 거주했던 한국인이 건설한 왕국으로 그 기원은 한국인의 영역 내에 있으며 그 후 세력은 오늘의 중국 동북지역 남부까지 확대되었다. 고구려는 중국 왕조와 대등한 관계였다. 고구려는 한국사의 일부이다.

“Their” Chinese Wikipedia entry header: “中国高句丽” in Chinese, with a pull-out in Korean: “【한국어 번역】 중국의 고구려”

“Their” text:【Korean Translation】【한국어 번역】 중국의 고구려는 중국의 동북지역 고대민족이 건설한 왕국으로 그 기원은 중국인의 영역 내에 있으며 그 후 세력은 한반도까지 확대되었다. 중국 왕조는 고구려를 속국으로 보고 고구려의 왕은 중국 황제에 의해 임명되었다. 고구려는 중국사의 일부이다.

Manipulation check: 위키백과의 설명과 지도를 보면 고구려는 한국인의 국가이다.

Intergroup emotions: 위키백과의 항목과 지도를 보신 후에 한국인으로서 다음의 감정을 어느 정도로 강하게 느끼셨습니까? Embarrassment (당혹감), pride (자부심), and anger (분노), assessed from (전혀 느끼지 않음) to (매우 강하게 느낌).

Dis/like: 귀하께서는 _ 을 얼마나 싫어하는지 혹은 얼마나 좋아하는지 -5점에서 5점 사이의 점수를 매겨주십시오. -5점은 매우 싫어하는 것을, 5 점은 매우 많이 좋아하는 것을 의미합니다.

Foreign policy preferences:

1. 한국은 중국과의 협력을 줄여야 한다.

2. 한국이 아시아를 선도하는 강한 나라가 되는 것이 우리 외교정책의 우선적인 목표가 되어야 한다.

3. 남한과 북한이 반드시 통일되어야 한다는 것이 나의 진정한 소망이다.

Debrief: 참가해 주셔서 감사합니다. 질문지에 나온 위키백과 항목은 가상의 항목입니다. 우리 조사팀은 귀하께서 어떻게 반응하는지를 연구하려고 합니다. 귀하의 답변은 익명으로 기록될 것입니다. 
Nationalism: 한국이 다른 나라에 비해 얼마나 우월한 나라라고 생각하십니까? Assessed from (매우 우월하다) to (전혀 우월하지 않다).

Peter Gries (corresponding author; peter.gries@manchester.ac.uk) is the Lee Kai Hung Chair and founding director of the Manchester China Institute, and professor of Chinese politics at the University of Manchester in the United Kingdom. He studies the political psychology of international affairs, with a focus on China and the US.

Yasuki Masui (masui@jura.niigata-u.ac.jp) is professor of East Asian Studies and Chinese Diplomacy at Niigata University in Japan, and guest professor at the School of International Studies at Peking University in China. He studies Chinese history and comparative politics between Japan and Korea.

Cite this article: Gries P, Masui Y (2022). How History Wars Shape Foreign Policy: An Ancient Kingdom and the Future of China-South Korea Relations. Journal of East Asian Studies 22, 1-21. https://doi.org/ $10.1017 /$ jea.2021.30 